\title{
BREXIT, Trumpism and the Agency of Populism in Contemporary Political Communication
}

Michael Ugorji*

DVG Konzulting 25, Angus Gardens, NW9 5LG, London, UK

\begin{abstract}
Donald J. Trump's presidency and Brexit happened to the world in a flash and that flash has refused to wane. The reality of these two major socio-political upheavals has rattled pundits and since posed the question of how the events came to be. This study addresses the tangential role played by populism, which by its amorphousness and lack of any particular ideological depth readily lends itself to the services of various forms of socio-political ends. Therefore, this paper argues that the capacity of populism, as an ambivalent and radical agent of mass movements, to effectively invade the political issues space and sustain or alter the course of sociopolitical action is pivotal to the strategies that energized Brexit and Trumpism, and eventually gave them unlikely victories. Digging into the depths of this agency unearths its strategic communications powers and also establishes its salience to contemporary political ideology and rhetoric.
\end{abstract}

Keywords: Political; Communication; People; Social

\section{Introduction}

Recent political discourses are being driven by a powerful current that is located in the remote sites of mass consciousness; and which at the moment seems unstoppable. Most researchers and analysts concerned with mass movements and their capacities to alter or sustain the course of sociopolitical action tend to agree that populism has grown to become an essential ideological stance that easily draws the masses' attention to their own insecurities and subconscious aspirations; emboldens their resistance or advocacy thereof; and invites them to make salient choices, guided or unguided, to respectively alter or foster those insecurities and aspirations.

Populism has been defined primarily as a specific political communication style or a political style that essentially displays proximity of the people, while at the same time taking an "antiestablishment stance" and emphasizing an idealized homogeneity of the people by the exclusion of specific segments of the entire population [1]. It has also been described as a thin-centered and analytically limited ideology which advocates the sovereignty of the people as a homogeneous entity [2,3]. These perceptions of populism as a complicated, limited and conflicted ideological stance create spaces for malleability and possible exploitation by politically engaged individuals and collectives to apply it for mass manipulation purposes. This paper will demonstrate that in subsequent sections with instances from Brexit and Trump's campaigns. Stanley [3] describes populism as "a 'thin' ideology which, although of limited analytical use on its own terms" interacts well with "the established ideational traditions of full ideologies". Hence, despite its lack of ideological depth and limited capacity for analysis, populism interacts with well-established ideologies such as liberalism, Christianism, Islamism, gender politics, left and right-wing radicalisms, among other isms. This interactional flexibility with other ideological perspectives answers to its frequent adoption in the promotion of various mass-targeted ideological campaigns. Thus, populism transcends its purview as an ideological stance to become a motif of a kind in the execution of politicallyactivated ideological campaigns; such as those run by Donald Trump and the Brexiteers during the 2016 presidential election campaigns in the United States and the EU referendum polls in the United Kingdom.

Populism has also been depicted as "a political response that favors popularity over other policy considerations", therefore endorsing another view that casts it in the light of that which "depoliticizes the political and hyper-politicizes social relations" [4,5]. According to Panizza [4], populism also blurs the line between the public and the private and "brings into the political realm both individual and collective desires that previously had no place in public life". Therefore, populism could be said to freely lend itself to various forms of topical social debates, cultural politics and mass movements.

\section{Methodology}

That populism was a seminal agent in the successes of the 2016 US presidential campaigns of Donald Trump and the UK EU-Referendum (Brexit) has been variously established by researchers, but the depth of that agency is what this paper dwells on. The discourse in this paper therefore, begins with a concise review of the radical concept of populism and progresses to explore the other concepts (Trumpism and Brexit) through the lens of populism. This has been done utilizing evidence from various sources comprising primary texts from Brexit and Trumpian campaigns, peer-reviewed research articles, a few influential Op-eds, as well as editorials where necessary; in order to give a proper perspective to the ensuing discourse.

\section{The fodder of populism}

It would be necessary to mention a few factors that give rise to populism with a gaze on right-wing populist movements which in many ways relate to both Brexit and Trumpian campaigns. Chief among these factors is the rising global income inequality and its attendant sociopolitical tensions. Peters and Volwahsen [6] identified three factors that have been in the forefront in driving higher income

*Corresponding author: Michael Ugorji, International Strategic Communications Consultant and Independent Researcher, DVG Konzulting 25, Angus Gardens, NW9 5LG, London, UK, Tel: +4915175566299; E-mail: odichidan@yahoo.com

Received November 26, 2017; Accepted December 28, 2017; Published January 02, 2018

Citation: Ugorji M (2018) BREXIT, Trumpism and the Agency of Populism in Contemporary Political Communication. J Mass Communicat Journalism 8: 355. doi: 10.4172/2165-7912.1000355

Copyright: @ 2018 Ugorji M. This is an open-access article distributed under the terms of the Creative Commons Attribution License, which permits unrestricted use, distribution, and reproduction in any medium, provided the original author and source are credited. 
inequality since 1995, namely: globalization, technological change and migration. This is however not to say that these factors have not had a real positive impact on aggregate income. It is these factors and the economic frictions that they generate that have given rise to the recent wave of right-wing populism in the western hemisphere; such as those that yielded Brexit and Trumpian sentiments. The masses that are worst hit by the fallout of these 'adverse' developments and the attendant economic inequality that they generated began to react and get restive about their precarious condition, giving rise to the new wave of populism.

Of all necessitating factors, globalization appears to be the chief culprit. Globalization in its wake brought along certain socioeconomic dynamics which have created both winners and losers of new globalized economic systems in Western Europe and North America. It has also created "distributional frictions between winners and losers" [7]. The eventual losers of globalization tend to be easily lured to the divisive rhetoric of right-wing populist parties [6-11]. It is then not surprising that the demographic most susceptible to Brexit and Trumpian rhetoric and which were most animated in their support of these campaigns, comprised the classical losers of the new economic order; rural-dwelling, middle-class and working-class natives, as will be demonstrated below.

Hence, globalization being a determining factor, exhibits "the potential to alter the political issue space as well as the institutional opportunities available to political actors"; thereby enhancing its propensity to drive support for radical right populist (RRP) parties and their ideas $[8,12]$. This explains the recent growth of RRPs in Europe, which exploit the fears and vulnerabilities of the citizens to win support by championing tough immigration laws and proposing a less powerful European Union $[7,9,12]$.

It would be recalled that at the end of a vicious and divisive Brexit campaign season between the Remainers and the Leavers in the 2016 UK EU-Referendum, a combination of factors succeeded in shaping public opinion and attitudes towards the EU and further integration. These factors include, but are not limited to: the escalating refugee crisis chiefly emanating from the Libyan, Iraqi and Syrian wars, alongside anti-multiculturalism activism, the fears of increased terrorism and cultural infiltration; socio-economic tensions and inequalities that keep widening with furious globalization and technological advances; and the participation of a Eurosceptic press that "provided the backdrop to all debates on European integration, reinforcing, and in turn reinforced by, the reluctance of pro-membership politicians" who failed to publicly present a strong positive case for remaining in the EU [13,14]. According to Pettifor [15] the 'Brexit' vote simply represents the latest manifestation of "popular dissatisfaction with the utopian ideal of autonomous markets beyond the reach of regulatory democracy"; a collective often misguided, "efforts of those 'left behind' in Britain to protect themselves from the predatory nature of market fundamentalism". This is therefore a form of social self-protection by the people from self-regulating markets on issues of money, trade and labour [15].

Other factors that directly or indirectly stimulate the rise and growth of populism, particularly in Western Europe and North America, range from economic and cultural to socio-political upsets and failures of leadership in recent years. These myriads of factors include: technological change, mass migration, neoliberal capitalism, 'liberal authoritarianism', the 2008 great recession, backlash from the prevalent multiculturalism occasioned by globalization, the Eurozone crisis and growing Euroskepticism, the dilemmas of representative politics in Europe, politicized policy practice, protest, anti-mainstream sentiments and all sorts of unfulfilled expectations, etc $[6,7,9,10,16-19]$. These factors have to varying degrees instilled fear or resentment, and also induced nationalistic feelings and sentiments among the citizenry, and rendered them vulnerable to populist ideologues and xenophobic RRP parties; who simply cash in on this loophole to enlarge their followership. It is also important to note that some of these factors either spin off from globalization and its corollaries or are closely associated with them.

\section{Populism in paradigmatic relations}

Since populism or populist relationships function in a directional dynamic, it would be crucial to further explicate that directional phenomenon as it relates to this paper. According to Brubaker [20], national populism is a polemic; an 'us' and 'them' relationship that operates in both vertical and horizontal dimensions. In the vertical dimension, the opposition operates between 'the people' and 'the elite'; where 'the people' refers to the 'ordinary' people (or as Donald Trump styled them, the 'forgotten men and women of our country'). "The elite" is seen as corrupt, self-serving, paralyzed by political correctness, and, above all, out of touch with or indifferent to the concerns and problems of ordinary people" [20]. In the horizontal dimension, the opposition operates between insiders and outsiders: between 'people like us' who share our way of life and those on the outside who are said to threaten our way of life. This includes 'internal outsiders' or those living in our midst and who might even be citizens of the state, but are not regarded as part of the nation. The 'outside' also includes impersonal forces or institutions that are perceived as threat to our way of life or our security. These may include "globalization, unfettered trade, the European Union, radical Islam, and so on" [20]. It is usually on the horizontal dimension of the relationship that 'the people' vent their fears, anger and frustrations. Therefore, it is also on this site that the RRP parties and populist political leaders perform most of their manipulative strategies to win over and control the gullible enchanted masses who find a façade of solace in their soothing, but often hollow rhetoric. Trumpism and European national populism are noted to "bring the vertical and horizontal registers together by characterizing "the elite" - political, cultural, or economic - as "outside" as well as "on top"”. This way, the elite are portrayed as not only "insensitive to the economic struggles of ordinary people", but also "indifferent or condescending towards their way of life" [20-25].

Trumpism resulted from a combination of factors. These include growing disenchantment among the masses in the United States and Western Europe with their political leaders. These (mostly liberal) governments seemed disconnected from the insecurities of the masses in the context of the unrelenting effects of globalization and the crisis of neo-liberalism which has negatively affected a layer of the western middle classes and particularly 'white working classes' [21,26,27]. Globalization and neo-liberalism became the essential fodder for growing inequalities, thereby creating a fast widening gap between the winners and losers of the globalized socioeconomic order. Similarly, the vote to leave the EU came as a result of decades of misgivings and disapproval among certain sections of the citizenry in the United Kingdom towards their country's membership of the continental body. It has been argued that these ill-feelings may have been allowed to blossom as a result of the diffidence of Britain's political elites towards domestically promoting the benefits of EU membership and highlighting notable British successes in shaping the EU. Thus Euroscepticism has been allowed to evolve both out of the negligence of political leaders and the lack of adequate information on the part of 
the ordinary man on the street.

\section{Between Brexit and Trumpism}

In the foregoing, Trumpism and Brexit can be said to be akin to each other in view of their emergence as reactionary sociopolitical behaviour driven by popular discontent, protest and populism. In what Adam Quinn [24] refers to as 'the unthinkable', Britons voted to leave the European Union, while Americans voted to elect Donald Trump as president, against conventional rationale and in a total slight of the established order. In the core of these two major political upsets and phenomena lies 'anger'; this led to bitter battles among the citizens against perceived insensitive leadership in the face of escalating socioeconomic inequalities and cultural backlash [28-30]. According to Ramswell [29], the UK and the USA each found their homelands embroiled in bitter battles raging among their citizenry in 2016 . He argues that the Leave/Stay campaigns in the UK and the 2016 US presidential campaign precipitated a rebirth of nationalism; when what began as good intentions for positive change quickly morphed into battlegrounds of derision and division waged by reinvigorated and enchanted populations. Smith [30] ascribes these manifestations of anger (or as she puts it, "Mad as hell" moment) to "the sluggish world economy, migration crisis, and negativity towards globalism".

The recent wave of mass migrations from the Middle East and Africa into Europe and the persistent immigration flux of people from Latin America into the United States, alongside the cultural diversities that they bring with them, have raised much fear and apprehension from the citizenry in the target regions. Hence, Western Europe and the USA have been rendered fertile grounds for the breeding of fervent nationalistic sentiments that easily evolved into ferocious antiimmigrant populist movements. In the view of Ramswell [29], racism and xenophobia have been transformed from isolated issues affecting only small portions of a society to become preeminent issues of debate and have also been given a vantage position in political warfare as obtained in the USA and the UK in 2016. However, the rise of antiimmigrant sentiments in Europe and the USA could be attributed to issues beyond racism, misogyny and xenophobia; such as dearth of jobs, wages and lack of sundry opportunities.

\section{Brexit and trumpism: the agency of populism}

Populism has been widely identified by experts to be the driving force for Trumpism, Brexit and many other recent manifestations of right-wing political activism; such as in Poland, France, Austria, the Netherlands and with the AFD ${ }^{2}$ in Germany. As already established above, populism thrives on mass movements and propels them as well, irrespective of what their proclivities are on political ideology. Populist forces proved decisive for the outcome of the British EU referendum, with their leaders allegedly igniting anti-immigrant and nativist sentiments in England; while Donald Trump similarly exploited the notable support for populism in the USA. In both cases, popular discontent and revolt against the establishment have fuelled the raging populist fire. Trump and his radical right party (RRP) counterparts across the Atlantic, the National Front in France and the United Kingdom Independence Party (UKIP) among others, rode the waves of ongoing frustrations; socioeconomic inequalities and cultural backlash. All of these factors are fallout of globalism. Globalization therefore, effectively created a dichotomy between winners and losers and consequently generated popular discontent and political revolt, which in turn fueled the fire of populism in the western hemisphere. Hence, Donald Trump, like most of his RRP counterparts in Europe, got his largest votes from the classical 'losers' of globalization contrary to the performance of his opponents. A majority of this Trump voter demographic are older Midwest-dwelling (Rust Belt) and blue-collar white male who are most likely to have lost their privileged access to the jobs they once had on a platter. Similarly, it was mostly the lesseducated, non-cosmopolitan, poorer and older voter across the Atlantic that mostly favored Brexit [31-34]. Analyses of the demographic spread of the Brexit vote paints a clearer picture of this pervading palpable fear and resentment for globalization among older folks. As Calhoun [32] observes, "Fully 75 percent of those aged 18 to 24 voted for a future in Europe. Sixty one percent of those over 65, along with a majority of all those over 45 , voted against". Regions with lower GDP per capita and a high proportion of lowly educated people, where the median age is over 65 and with strong net immigration have also shown more propensity to be apprehensive of the EU and immigration [31,32].

As ongoing research demonstrates, Brexit (like Trumpism) was not only a protest against socioeconomic inequalities occasioned by globalization, but also arguably a vote for some version of the past; "a nostalgic reaching back to the past in order to redeem the present" $[32,33,35]$. Both of these events also happened as a reaction against the establishment elite for their perceived cultural and political marginalization of ordinary people who hold traditional values. Thus, as Michel Bauwens and Vasilis Niaros note, "Trumpism and Brexit could be seen as reactions against the effects of neo-liberalism and its destruction of the middle class". In the last few decades, the western world has been largely ruled by liberal (or at least, centre-right) parties whose values are essentially at variance with those of traditional, religious and conservative societies. Extensive research indicates that since about 1970, there has been a cultural shift to post-materialist and self-expression values among the younger birth cohorts and the better educated strata of affluent Western societies. According to Ronald Inglehart and Pippa Norris, this cultural shift has fostered greater approval of social tolerance of diverse lifestyles, religions, and cultures, multiculturalism, international cooperation, democratic governance, and protection of fundamental freedoms and human rights. Social movements reflecting these values have brought policies such as environmental protection, same sex marriage, and gender equality in public life to the center (sic) of the political agenda, drawing attention away from the classic economic redistribution issues.

To heighten the conflict described above, Enoch [24] observes that these liberal values "were shoved down the throat of those left behind, without ever asking for their opinion, and at their expense" and with arrogant, patronizing, alienating attitudes by the elites. These 'arrogant' neoliberal elites in what has been described as, 'liberal authoritarianism', took these masses for granted and stifled their voice both intellectually or politically; hence the seeds of discord that would grow into abrasive cultural backlash had been sown $[20,21,23,24]$. The spread of these liberal progressive values in the West, especially in the USA and the UK, eventually stimulated a cultural backlash among people who felt threatened by the rapid change. Less educated and older white men, who had been the privileged majority culture in Western societies, to their chagrin soon found them being tagged 'politically incorrect' for holding their traditional values. This culture shift became unacceptable, hence the populist revolt [23].

On another cultural front, Western Europe had its fair share of turmoil with the immigration crisis that came mostly as fallout of the anomalous Iraqi and Syrian wars and before those the civil war in Libya. Refugees, either fleeing state-sponsored violence or Islamist jihad of the Islamic State of Iraq and the Levant (ISIL or ISIS), came 
in droves through many routes into Western Europe and the threat of infiltration by ISIS terrorists became real when some of the new arrivals launched attacks in various European cities. To heighten the tension, the new refugees from predominantly Islamic-Sharia cultures experienced initial culture shocks to which some of them responded very badly. The European natives were also alarmed when some of the new arrivals were reported to have engaged in rape and sexual molestation acts among other indecent behaviour. In the midst of all these, the governments and liberal elites in the Western world seemed to have stood aloof to the plight of the people. They appeared to be more "concerned with the rights and welfare of distant others but indifferent to the struggles of proximate brothers and sisters"; promoting a world without borders, not mindful of its "destructive effects on the bounded solidarities of nation and community" [20]. The natives were outraged at the express welcoming of immigrants and refugees by these liberals who tended to favour and promote unbridled mixing and multiculturalism. In the USA, this populism escalated when Hilary Clinton characterized Trump supporters as "a basket of deplorables"; typical of the liberal condescending denouncing of ordinary people as racist and Islamophobic whenever they speak up, while expressly "speaking for minorities rather than the majority" [20]. Consequently, general disenchantment with government, fear of terrorism, and resentment towards foreigners increased. These incidents therefore compounded arguably hitherto benign anti-Muslim immigration sentiments across Europe which conflagrated, spilling over into the United States close to major elections. Siobhan Kattago notes that the ideas upon which the EU was founded (human rights, tolerance and the free movement of people) were stretched to their limits by these incidents: "ranging from hospitality to hostility, 'refugees welcome' to 'close the borders', asylum seekers from Syria and other war-torn countries", etc. The clamour for closing the borders of Europe escalated and this boosted the resolve of the Brexiteers to take total advantage of Prime Minister David Cameron's offer of a UK EU-Referendum in 2016. In the USA, candidate Trump promised to ban people from Muslim countries from entering his country if he became president. Donald Trump did become president and has been trying to enforce that ban, despite having to scale hordes of legal hurdles.

In all of these, populism (both of the left and the right) took centre stage and has been quickly hijacked by politicians who exploit it simply to win elections. Various issues and pseudo-ideologies also came to the fore including; alt-right (alternative right) nationalism, secularism, Islamism, Christianism or 'identitarian' Christianism, even neoMarxism, etc. These ideologies and concepts may have been pushed to the fore not based on their primal salience to the lived experiences of the individual citizen in the West, but based on their expedience as sites of resistance and escape routes from a feared imminent cultural infiltration or outright cultural transposition. They also address the fear of losing perceived social and economic advantages. In the core of these reactionary activisms resides populism which has been variously described as a pathological political phenomenon, a style, a syndrome and a doctrine $[3,36]$.

The ambivalence and ambiguousness of the activism of recent populist movements in the western hemisphere are illuminated by their reactionary and anti-immigration stance. As Brubaker [20] observes, Trump and Euro-populists, like all populists everywhere, "claim to speak in the name of "the people": "I am your voice", said Trump at the culminating moment of his acceptance speech at the Republican convention". Even Nigel Farage of UKIP positioned himself as the voice of liberation for people of the United Kingdom against the 'tyranny of Brussels' and has gone further to establish a radio talk-show after the
Brexit vote to sustain his claim to that tag. Trump with his refusal to be 'politically correct' on the issues of concern to the stifled voices, quickly became the poster-child of resistance for the oppressed "forgotten men and women of our country", and of course of other western societies. He openly backed Brexit and reciprocally, "UKIP leader Nigel Farage not only praised him but actually spoke at one of his febrile rallies", even when other British politicians chose to distance themselves from Donald Trump [24].

\section{Conclusion}

The two stunning upsets, Brexit and Trumpism, could be said to have defined the national populist moment for both the United Kingdom and the United States. Brexit and the Brexiteers rode on the back of populism to drag the UK out of the European Union, while Trump, Trumpism and Trumpeteers also rode on the back of populism to upset the ante and take the US presidency in a most shocking campaign victory. Nationalist populism in both countries blossomed and operated in binaries of two dimensions: the vertical and the horizontal. Trumpism and European national populism (Brexit and others) managed to bring together the vertical and horizontal registers of populism by characterizing "the elite" - political, cultural, or economic - as both "outside" and "on top" in the 'us-them' polemics of socioeconomic order. These elite have been portrayed "not only as insensitive to the economic struggles of ordinary people, but also as indifferent or condescending towards their way of life". In the vertical relationship, accord has been breached on the economic front, while the social contract has also been breached on the political and cultural fronts in the horizontal relationship. Hence, "the people" who are also the "insiders" revolted and rejected "the elite" who are also the "outsiders". Thus, populism remains that essential fabric that its capacity for agency and deployment of that agency could never be over-estimated in contemporary political communication discourses.

\section{References}

1. Jagers J, Walgrave S (2007) Populism as political communication style: An empirical study of political parties' discourse in Belgium. European Journal of Political Research 46: 319-345.

2. Abts K, Rummens S (2007) Populism versus Democracy. Political Studies 55 405-424.

3. Stanley B (2008) The thin ideology of populism. Journal of Political Ideologies.13: 95-110.

4. Panizza F (2005) Populism and the mirror of democracy. London: Verso.

5. Roberts JV, Stalans LI, Indermaur D, Hough M (2003) Penal populism and public opinion - Lessons from 5 countries. Oxford University Press

6. Peters H, Volwahsen M (2017) Rising Income Inequality: Do Not Draw the Obvious Conclusions, Intereconomics 52: 111-118.

7. Dippel C, Gold R, Heblich S (2016) Globalisation and anti-globalisation voters: Evidence from Germany. VOX CEPR's Policy Portal.

8. Farrell H, Newman A (2017) BREXIT, voice and loyalty: rethinking electoral politics in an age of interdependence. Review of International Political Economy 24: $232-247$.

9. Ramiro L, Gomez R (2016) Radical-Left Populism during the Great Recession Podemos and Its Competition with the Established Radical Left. Political Studies 65: 108-126.

10. Taggart $P$ (2004) Populism and representative politics in contemporary Europe. Journal of Political Ideologies 9: 269-288.

11. Swank D, Betz H (2003) Globalization, the welfare state and right-wing populism in Western Europe. Socio-Economic Review 1: 215-245.

12. Steenbergen MR, Siczek T, Steenbergen MR (2017) Better the devil you know? Risk-taking, globalization and populism in Great Britain. European Union Politics 18: 119-136. 
Citation: Ugorji M (2018) BREXIT, Trumpism and the Agency of Populism in Contemporary Political Communication. J Mass Communicat Journalism 7: 355. doi: 10.4172/2165-7912.1000355

Page 5 of 5

13. Menon A, Fowler B (2016) Hard or Soft? The Politics of Brexit. National Institute Economic Review 238: R4-R12.

14. Deacon D, Wring D (2016) The UK Independence Party, populism and the British news media: Competition, collaboration or containment?. European Journal of Communication 31: 169-184.

15. Pettifor A (2016) Brexit and its Consequences. Globalizations, Taylor and Francis Online.

16. Brack N, Startin N (2015) Introduction: Euroscepticism, from the margins to the mainstream. International Political Science Review 36: 239 - 249.

17. Hinterleitner M (2017) Policy failures blame games and changes to policy practice. Journal of Public Policy

18. Wagner M, Meyer TM (2017) The Radical Right as Niche Parties? The Ideological Landscape of Party Systems in Western Europe, 1980-2014. Political Studies 65: 84-107.

19. Wellings B, Vines E (2016) Populism and Sovereignty: The EU Act and the InOut Referendum, 2010-2015. Parliamentary Affairs 69: 309-326.

20. Brubaker R (2017) Between nationalism and civilizationism: the European populist moment in comparative perspective. Ethnic and Racial Studies 40: 1191-1226.

21. Bauwens M, Niaros $\vee(2017)$ Re-dynamising Local Economies in the Age of Trumpism. Journal of Futures Studies 21: 101-106.

22. Enoch D (2017) The Masses and the Elites: Political Philosophy for the Age of Brexit, Trump \& Netanyahu. Jurisprudence An International Journal of Legal and Political Thought 8: 1-22.

23. Inglehart R, Norris $P$ (2016) Trump, Brexit, and the Rise of Populism: Economic Have-Nots and Cultural Backlash. HKS Working Paper, No. RWP16-026.

24. Quinn A (2017) The UK should expect no favors from the new president: Trump will look out for Trump. USApp - American Politics and Policy.
25. Spierings N, Lubbers, M, Zaslove A (2016) Sexually modern nativist voters': do they exist and do they vote for the populist radical right?. Gender and Education 29: $216-237$

26. Blyth M (2016) Global Trumpism: Why Trump's victory was 30 years in the making and why it won't stop here. Foreign Affairs.

27. Stoetzer M, Gerlich S, Koesters J (2017) Trump's first triumph: The US republican primaries 2016 - An analysis of socio-demographic, time-related and regional influences. Jenaer Beiträge zur Wirtschaftsforschung, No. 2017/2.

28. Avlijaš S (2016) From Brexit to Trump: why mobilising anger in a constructive way is now one of the key challenges in modern politics.

29. Ramswell PQ (2017) Derision, division-decision: parallels between Brexit and the 2016 US presidential election, European Political Science16: 217-232.

30. Smith M (2016) Trump, Brexit, and the West's "Mad as hell" moment. USApp American Politics and Policy.

31. Arnorsson A, Zoega G (2016) On the Causes of Brexit. CESifo Working Paper Series, 6056.

32. Calhoun C (2016) Brexit is a mutiny against the cosmopolitan elite. New Perspectives Quarterly 33: 50-58.

33. Cavaillé C, Gidron N, Hall PA (2016) Trumpism as a Transatlantic Phenomenon The American prospect.

34. Hobolt SB (2016) The Brexit vote: a divided nation, a divided continent. Journal of European Public Policy 23: 1259-1277.

35. Tarnopolsky C (2017) Melancholia and Mania on the Trump Campaign Trail. Theory \& Event 20: 100-128.

36. Kaltwasser CR (2012) The ambivalence of populism: threat and corrective for democracy. Democratization 19: 184-208. 